九州大学学術情報リポジトリ

Kyushu University Institutional Repository

Comparative Studies on Biological and

Serological Properties of Turnip Mosaic Virus Isolates

Choi, Jang Kyung

Matsuyama, Nobuak i

Laboratory of Plant Pathology, Faculty of Agriculture, Kyushu University

Wakimoto, Satoshi

Laboratory of Plant Pathology, Faculty of Agriculture, Kyushu University

https://doi.org/10.5109/23716

出版情報: 九州大学大学院農学研究院紀要. 25 (1)，pp. 15-23，1980-08. Kyushu University バージョン：

権利関係 : 


\title{
Comparative Studies on Biological and Serological Properties of Turnip Mosaic Virus Isolates
}

\author{
Jang Kyung Choi, Nobuaki Matsuyama \\ and Satoshi Wakimoto \\ Laboratory of Plant Pathology, Faculty of Agriculture, \\ Kyushu University 46-01, Fukuoka 812
}

(Received January 26, 1980)

\begin{abstract}
Based on the symptoms on Brassica rapa L. cv. Hakatasuwari, eight isolates of ordinary strain of turnip mosaic virus (TuMV) collected from Japan could be differentiated into three groups, which were respectively designated as OA, OB and OC groups. Biological and serological properties of the virus isolates belonging to these groups were compared from each other. All isolates were almost identical in host range, electrophoretic mobility and in agar gel immunodiffusion test, however, they were much different in some of the other properties such as symptoms on several indicator plants, local lesion size on Nicotiana tabacum L. cv. Samsun, mode of multiplication in B.rapa, physical properties, and serological properties in micro-precipitin test. Some of these properties showed variation correlating with the groups.
\end{abstract}

\section{INTRODUCTION}

The biological and serological properties of turnip mosaic virus (TuMV) isolates have been reported by several workers (Tompkins, 1938; Pound, 1948; Pound et al., 1962; Yoshii et al., 1963; Tochihara, 1965; Provvidenti, 1978). Yoshii (1963) divided TuMV isolates into two strains, ordinary strain and cabbage strain, according to the symptoms appeared on Nicotiana glutinosa and cabbage (Brassica oleracea L. var. capitata). The ordinary strain which produces mild symptom on N. glutinosa (Yoshii et al,, 1963) is known to be commonly distributed on turnip and radish in Japan. By means of compliment fixation test, Tochihara (1961) serologically classified TuMV isolates into two strains, $\mathrm{P}$ and $R$. Such differences were reported to exist among the isolates but they did not carry out comparative studies on the characteristics of the isolates in any detail.

The following investigation was conducted to compare biological properties of the isolates and to set up some criteria for possible grouping of the isolates.

\section{MATERIALS AND METHODS}

\section{Virus sources}

Eight isolates of TuMV ordinary strain were used in this work. A typical 
isolate of the ordinary strain, No. 67, first reported by Yoshii et al. (1963) was maintained in our laboratory. An isolate from rape (Tochihara, 1965) (C 10) was provided by Dr. H. Tochihara of the Institute of Plant Virus Research, Japan, and that from iris (Inoue and Mitsuhata, 1978) ( $\operatorname{Ir} 16$ ) from Dr. N. Inoue of Okayama University. The isolates $\mathrm{T} 3$ and $\mathrm{T} 17$ were obtained from turnip leaves collected respectively from Fukuoka and Mie Prefectures, and Rd 28, Rd 29 and Rd 34 were obtained from radish leaves in Fukuoka Prefecture. All isolates were maintained on turnip (B. rapa L. cv. Hakatasuwari) by mechanical transmission in air conditioned green-house.

\section{Symptoms on host plants}

All test plants were raised under the same conditions in a temperature controlled $\left(20-27^{\circ} \mathrm{C}\right)$ green-house. To compare the symptoms on turnip, 25day old plants after sowing (15-day after transplanting) were inoculated. For testing host range, six to ten plants of each species were used. The symptoms on the inoculated plants were observed periodically for a month, and then each isolate was back-inoculated to turnip to test whether they still maintain the pathogenicity to cause original symptoms or not.

The inoculum was prepared by homogenizing systemically infected turnip leaves with 2 volumes of $0.1 \mathrm{M}$ phosphate buffer ( $\mathrm{pH} 7.0$ ), and inoculation was made by rubbing Carborundum (400 mesh) dusted leaves with a cotton swab impregnated with the inoculum.

\section{Mode of multiplication}

To make clear the mode of multiplication of TuMV isolates on turnip plants, 25-day old plants were inoculated and virus concentration was assayed periodically at $5,10,15,20,25$ and 30 days after inoculation. For assaying virus concentration, the inoculum was prepared by homogenizing five completely expanded leaves with 5 volumes of $0.1 \mathrm{M}$ phosphate buffer $(\mathrm{pH} 7.0)$. The relative infectivities of the isolates were determined by counting the number of local lesions appeared on 12 half-leaves (Kuhn, 1965) of N.tabacum L. cv. Samsun.

\section{Physical properties}

To test the physical properties of TuMV isolates, inoculum was prepared by homogenizing systemically infected turnip leaves with 5 volumes of the phosphate buffer. Six turnip plants were inoculated with each virus isolate in every experiments. In thermal inactivation test, undiluted inocula were heated in a water bath at different temperatures of $5^{\circ} \mathrm{C}$ intervals ranging from $50^{\circ} \mathrm{C}$ to $70^{\circ} \mathrm{C}$ for $10 \mathrm{~min}$, cooled immediately with ice, and infectivities were assayed. To determine the longevity in vitro, the inocula stored for different periods $\left(1,2,4\right.$ and 6 days) at room temperature (about $20^{\circ} \mathrm{C}$ ) were inoculated. To determine the dilution end point, each preparation was diluted with $0.1 \mathrm{M}$ phosphate buffer ( $\mathrm{pH}$ 7.0) to make concentrations from $10^{-1}$ to $10^{-5}$ and their infectivities were assayed. 


\section{Electrophoretic mobility}

Electrophoretic mobility of intact virus of each isolate was tested by the method of Makkouk and Gumpf (1976). The crude sap from turnip leaves infected with each isolate was clarified by one cycle of differential centrifugation. The specimen thus obtained was electrophoresed in the gel composed of $1 \%$ polyacrylamide and $0.5 \%$ agarose. After running at $5 \mathrm{~mA} / \mathrm{gel}$ for $6 \mathrm{hr}$, thus gels were stained with $0.5 \%$ aniline black in $7 \%$ acetic acid and destained with $7 \%$ acetic acid.

\section{Serological relationship}

Antisera of the isolates 67 (Choi et al., 1978) and C 10 (Tochihara, 1965) were prepared by injecting purified viruses to rabbits. Agar gel double immunodiffusion test was performed for each isolate as previously described (Choi et al., 1978). The immunoplates incubated in a moist chamber at $20^{\circ} \mathrm{C}$ for 24-48 hr were washed with $0.1 \mathrm{M} \mathrm{NaCl}$ for $10 \mathrm{~min}$, dried and stained with $0.5 \%$ Coomassie Brilliant blue R 250 in the solution of $96 \%$ ethanol: acetic acid $:$ water $=4.5: 1: 4.5$. Antigen preparations to be tested were treated by ulfrasonication for $10 \mathrm{~min}$. The end point of serological reaction was detected by micro-precipitin test (Noordam, 1973) in Petri dishes with serially diluted antiserum and virus antigen.

\section{RESULTS}

\section{Symptoms on turnip}

All isolates caused typical mosaic symptoms on turnip (B. rapa L. cv. Ha-

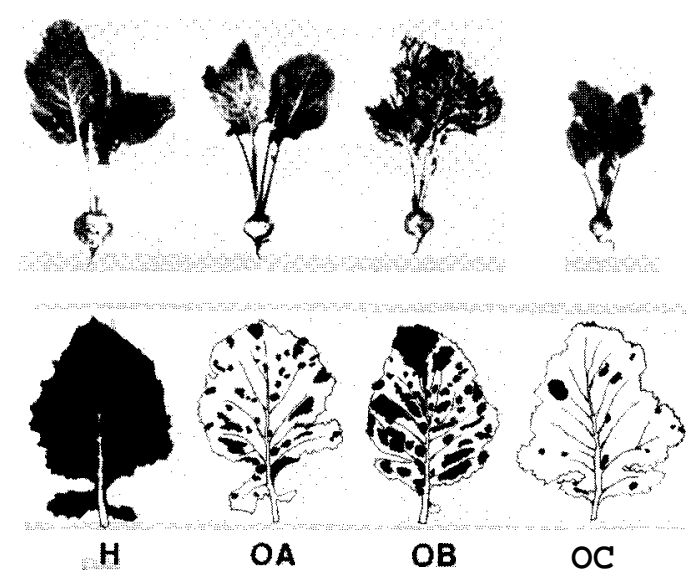

Fig. 1. Symptoms on turnip incited by different isolates of TuMV (O light green, and dark green). $\mathrm{H}$, healthy plant and its leaf; OA, plant and leaf infected with isolate 67; OB, those infected with Ir 16; and OC. those infected with C 10. 
katasuwari) leaves. The symptoms were classified into three types depending upon the proportion of light green area to dark green area. The isolates $\mathrm{C}$ 10, $\mathrm{T} 3$ and $\mathrm{Rd} 28$ caused stunting with greater proportion of light green area in mosaic symptom than the other isolates (Fig. 1 OC), and were designated as OC group. The isolate Ir 16 did not cause any stunting but mosaic on leaves with high proportion of dark green area (Fig. 1 OS), and was designated as OB group. The other isolates, 67, T 17, $\mathrm{Rd} 29$ and $\mathrm{Rd} 34$, caused a mosaic type of intermediate (Fig. 1 OA) between $\mathrm{OB}$ and $\mathrm{OC}$, and were designated as OA group. These three different symptoms could be distinguished about 20 days after inoculation and more clearly after 25-30days.

\section{Symptoms on different hosts}

Table 1 outlines the contrast in susceptibility and symptom expression on possible indicator hosts. On B. napus L. cv. Norin 14 and B. pekinensis Rupr. cv. Nozaki 2, the isolates C 10, Ir 16 and Rd 28 induced systemic symptoms. The symptoms of Ir 16 and C 10 were more severe than that of Rd 28. The isolate $\mathrm{T} 3$ caused mild symptom very rarely on $B$. pekinensis, however, isolates 67, $\mathrm{T} 17, \mathrm{Rd} 29$, and $\mathrm{Rd} 34 \mathrm{did}$ not incite any symptoms. On Trifolium incarnatum L., C 10 and T 3 caused systemic infection, while other isolates did not show any symptoms. All isolates caused necrotic local lesions on the leaves of Vicia faba L. cv. Sanuki-nagasaya and 6 isolates with exceptions of T 17 and Rd 34 caused also necrotic spots on Vigna sesquipedelis L. cv. Misawa. Stem necrosis was caused by $\mathrm{C} 10, \mathrm{~T} 3$ and Rd 28 on $V$. faba. All isolates induced local lesion on N. tabacum L. cv. Samsun, however, the size of lesions $0.23 \pm$ $0.08 \mathrm{~cm}$ diameter) caused by Ir 16 was larger than those by others $(0.14 \pm 0.06$ $\mathrm{cm}$ diameter) (Fig. 2). The plants Calendula officinalis L., Chenopodium amaranticolar L., Gomphrena globosa L., N. rustica L. and Phaseolus vulgaris L. were locally infected by all isolates, while Raphanus sativus L. and Spinacia oleracea L. systemically. B. oleracea L. var. capitata did not show symptoms by any isolates.

\section{Mode of multiplication}

With regard to multiplication of the isolates in turnip leaves, two patterns

Table 1. Symptoms on indicator plants incited by 8 isolates of TuMV.

\begin{tabular}{|c|c|c|c|c|c|c|c|c|}
\hline \multirow{2}{*}{ Host } & \multicolumn{8}{|c|}{ TuMV isolate } \\
\hline & 67 & $\mathrm{~T} 17$ & $\operatorname{Rd} 29$ & $\operatorname{Rd} 34$ & $\operatorname{Ir} 16$ & $\mathrm{C} 10$ & T3 & $\operatorname{Rd} 28$ \\
\hline $\begin{array}{l}\text { Brassica napus L. Norin } 14 \\
\text { B. pekinensis Rupr. Nozaki } 2 \\
\text { B. rapa L. Hakatasuwari } \\
\text { Trifolium incarnatum L. } \\
\text { Vicia faba L. Sanuki-nagasaya }\end{array}$ & $\bar{s}(\mathrm{M})$ & $\mathrm{s} \quad(\mathrm{M})$ & $\overline{s(M)}$ & $\bar{s}(\mathrm{M}) \mathrm{s}$ & $\begin{array}{l}\text { s } \\
\text { s.ns } \\
\text { (DG) }\end{array}$ & $\begin{array}{l}s \\
s \\
s(L G) \\
s \\
s, c s, s n\end{array}$ & $\begin{array}{c}\overline{[s]} \\
s \stackrel{(L G)}{s}\end{array}$ & $\begin{array}{ll} & s \\
s & (L G) \\
& \end{array}$ \\
\hline Vigna sesquipedelis L. Misawa & $\begin{array}{l}115 \\
\mathrm{~ns}\end{array}$ & $11 \mathrm{~s}$ & ns & 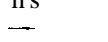 & ns & $\begin{array}{l}\text { 11s. Cs. S11 } \\
\text { n s }\end{array}$ & ns & $\begin{array}{ll}n \\
\mathrm{n} s\end{array}$ \\
\hline
\end{tabular}

s: Systemic infection. ns: Necrotic local lesion. cs: Chlorotic local lesion. sn: Stem necrosis. --: No infection. [s]: Occasionally appear. (DG): High proportion of dark green area in mosaic symptom. (LG): High proportion of light green area in mosaic symptom. (M): Intermediate type between the DG and LG types. 

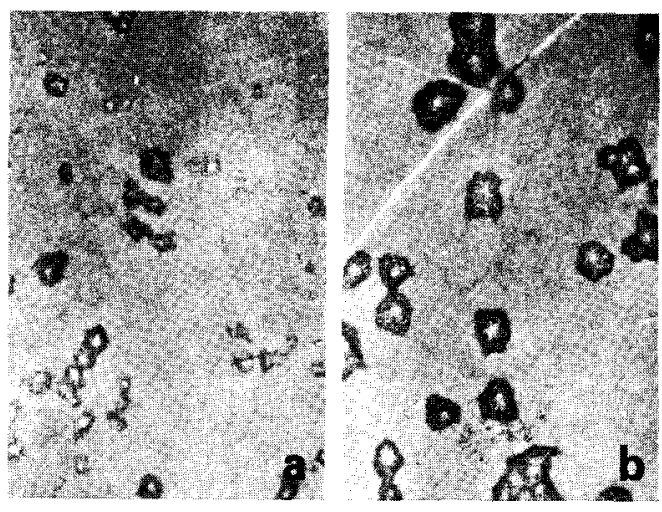

Fig. 2. Local lesions on N. tabacum L. cv. Samsun caused by inoculation with 67 (a) and Ir 16 (b).

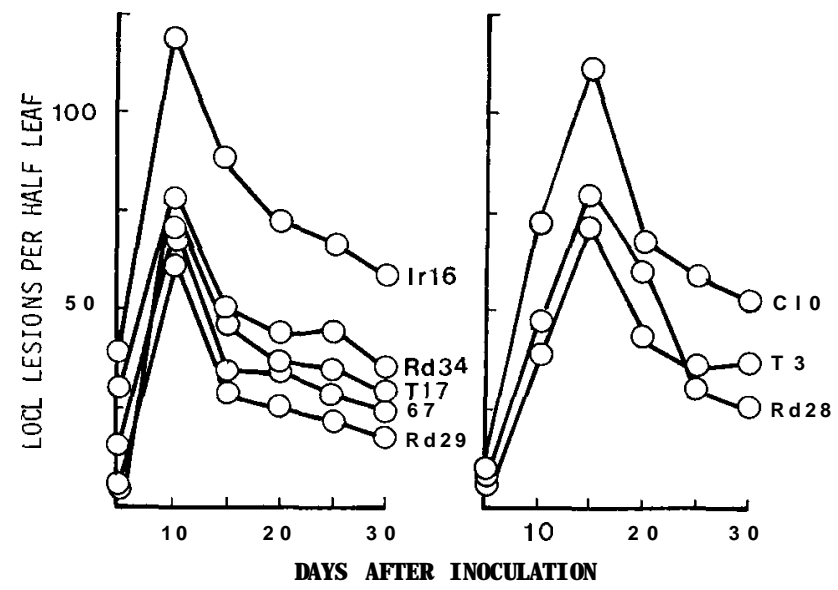

Fig. 3. Multiplication of TuMV isolates in turnip leaves. Local lesion number indicates the average number of lesions developed on 12 harfleaves of Samsun.

different each other depending upon the isolates were observed (Fig. 3). OA and $\mathrm{OB}$ group isolates showed the multiplication peak at 10 days after inoculation, but $\mathrm{OC}$ group isolates reached peak at about 15 days.

Physical properties

Physical properties of the TuMV isolates were as shown in Figure 4. The isolates 67 and $\mathrm{Rd} 34$ lost their infectivities by heating at a temperature higher than $60^{\circ} \mathrm{C}$ for $10 \mathrm{~min}$, while $\mathrm{C} 10$ and $\mathrm{T} 3$ did not even at $65^{\circ} \mathrm{C}$ for 10 min, and lost completely at $70^{\circ} \mathrm{C}$. The isolates, 67, T 17, Rd 28 and $\mathrm{Rd} 29$, maintained their activities for 2 days in crude sap, which was shorter than those of the other isolates. The isolate $\mathrm{C} 10$ was most stable and maintained infectivity for 6 days. Variation in dilution end point was not so large among 


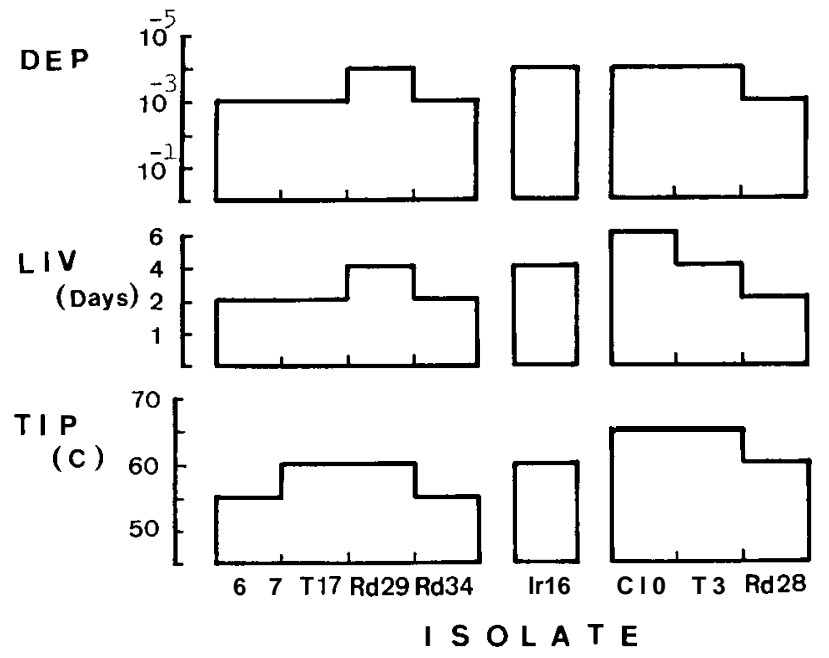

Fig. 4. Comparison of the $8 \mathrm{TuMV}$ isolates in physical properties. DEP, dilution end point; LIV, longevity in vitro; and TIP, thermal inactivation point.

isolates, showing $10^{-3}$ to $10^{-4}$.

\section{Electrophoretic mobility}

All isolates migrated toward the anode side at $\mathrm{pH} 8.2$ and gave a single band at the same $E f$ value. The distance of migration was similar to that of potato virus Y (PVY) described by Makkouk and Gumpf (1976).

\section{Serology}

All ultrasonicated isolates showed a homologous reaction when subjected to agar gel immunodiffusion test against anti-67 (Fig. 5)-or anti-C 10-serum, indicating serological identity among the isolates. However, when the isolates were tested against these two antisera for detecting reaction end point

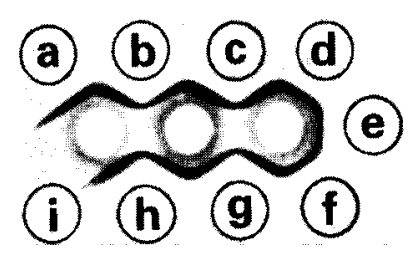

Fig. 5. Serological reaction of TuMV isolates sonicated for $10 \mathrm{~min}$. Peripheral wells labeled a, b, c, d, e, f, g and $h$ contained the sap from the plants infected with TuMV 67, T 17, Rd 29, Rd 34, Ir 16. C 10, T 3 and Rd 28. The well i contained the sap from healthy plant. Three center wells unlabeled contained anti-67-serum. 


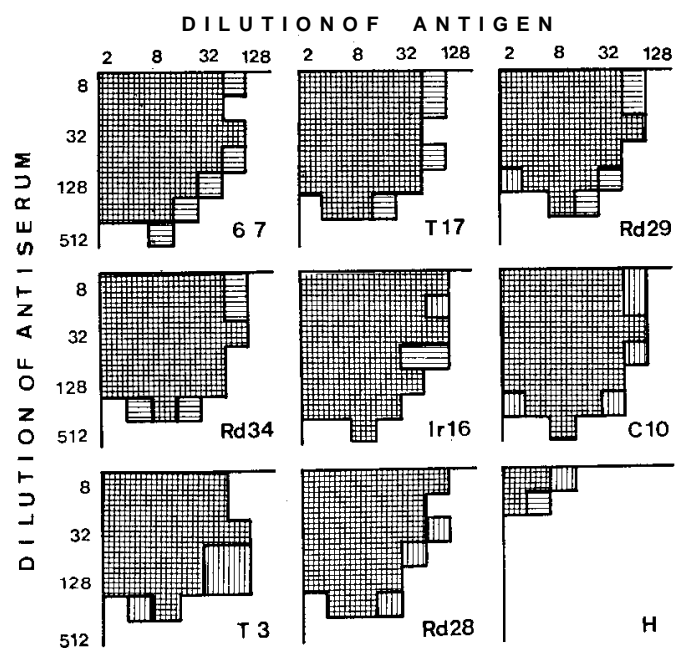

Fig. 6. End points of the reaction between two fold dilution series of antisera and TuMV isolates. precipitation range of each isolate with anti-67-serum; \|\|\|\|$\|$, those of each isolate with anti-C lo-serum.

by micro-precipitin test, slight differences were observed among the isolates (Fig. 6). The results suggest that the isolates could be divided into three groups. The first group including 67, T 17, $\mathrm{Rd} 29$ and $\mathrm{Rd} 34$ strongly reacted with anti-67-serum, and the second group, C 10, T 3 and $\mathrm{Rd} \mathrm{28,} \mathrm{did} \mathrm{with} \mathrm{anti-}$ C lo-serum. The third group, Ir 16, reacted similarly with both antisera.

\section{DISCUSSION AND CONCLUSION}

TuMV isolates were reported to be classified into two strains, viz. ordinary strain and cabbage strain (Yoshii, 1963). Almost all isolates from Japan are said to belong to the former strain (Yoshii, 1963). Furthermore, TuMV ordinary strain was divided into three groups on the basis of symptoms on $\mathrm{N}$. glutinosa (Yoshii et al., 1963). In this cases, however, other characteristics such as physical properties or host range did not correlate with the grouping.

Depending upon the symptoms on turnip, eight TuMV isolates used in this work were divided into three groups, viz. OA (isolates 67, T 17, Rd 29 and Rd 34), OB (isolate Ir 16) and $\mathrm{OC}$ (isolates $\mathrm{C} 10, \mathrm{~T} 3$ and $\mathrm{Rd} 28$ ). Among other biological and serological properties of the isolates, host ranges or symptoms on some indicator plants, and serological properties shown by micro-precipitin test partially supported the grouping mentioned above. The isolates belonging to the groups $\mathrm{OA}$ and $\mathrm{OC}$ produced smaller lesions on $\mathrm{N}$. tabacum L. cv. Samsun as compared to OB group isolate. According to the mode of multiplication in the tissue of turnip leaves, both groups $\mathrm{OA}$ and $\mathrm{OB}$ fell into the same group showing rapid multiplication, while OC group was quite different and multiplied slowly. Physical properties of the isolates such as thermal in- 
activation point, longevity in vitro and dilution end point did not show any meaningful difference among the grouping. These results suggest that the isolates belonging to the groups, $\mathrm{OA}, \mathrm{OB}$ and $\mathrm{OC}$ are distinguishable from each other in some biological or serological properties, however, all isolates were almost identical in electrophoretic mobility and in serological properties shown by agar gel immunodiffusion method.

The other twelve isolates collected from various localities of Japan were also divided into three groups depending upon symptoms on turnip. Among them, 8 isolates were known to belong to OA group and 3 isolates to OC group. Only one isolate was known to belong to OB group. From these results it will be concluded that the group OA seems to be most common, OC follows, and the isolate belonging to the group $\mathrm{OB}$ is very rarely distributed in Japan. This is also supported by the fact that the host ranges and symptoms of TuMV reported up to the present (Pound, 1948; Yoshii et al., 1963; Tochihara, 1965; Provvidenti, 1978) almost coincided with those of OA group.

Among serological techniques, the micro-precipitin test was reported (Noordam, 1973) to be useful for differentiating the isolates closely related from each other. Tochihara (1961) distinguished two antigenic variants in TuMV, radish $\mathrm{P}$ and $\mathrm{R}$, by compliment fixation test. The three groups differentiated with precipitin test in this study, however, did not show any correlations with Tochihara's two types.

\section{ACKNOWLEDGEMENTS}

We thank to Dr. H. Tochihara of the Institute of Plant Virus Research, Japan, for providing a TuMV isolate $(\mathrm{C} 10)$ and its antiserum, and to Dr. N. Inoue of Okayama University, Japan, for providing a TuMV isolate (Ir 16) used in this work.

\section{REFERENCES}

Choi, J. K., T. Maeda and S. Wakimoto 1978 Serological properties of turnip mosaic virus. Ann. Phytopath. Soc. Japan, 44: 14-21

Inoue. N. and K. Mitsuhata 1978 Turnip mosaic virus isolated from iris. Nogaku Kenkyu, 57: 1-16 (in Japanese)

Kuhn, C. W. 1965 Symptomatoiogy. host range, and effect on yield of a seed-transmitted peanut virus. Phytopathology, 55: 880-884

Makkouk, K. M. and D. J. Gumpf 1976 Characterization of potato virus Y strains isolated from pepper. Phytopathology, 66: 576-581

Noordam, D. 1973 Procedure of the micro-precipitin test in Petri dishes. In "Identification of Plant Virus," Pudoc, Inc., Wageningen, pp. 114-116

Pound, G. S. 1948 Horseradish mosaic. J. Agri.Res., 77: 97-114

Pound, G. S., H. Tochihara and R. J. Shepherd 1962 Relationship between turnip mosaic virus and the radish $\mathrm{P}$ virus of Japan. Phytopathology, 52: 373

Provvidenti, R. 1978 A mosaic of Pisum sativum caused by a strain of turnip mosaic virus. PI. Dis. Reptr., 62: 482-485

Tochihara, H. 1961 Studies on the viruses of Japanese radish mosaic diseases IV. Sero- 
logical relationship between radish $\mathrm{R}$ virus and $\mathrm{P}$ virus. Ann. Phytopath. Soc. Japan, 26: 125-130 (in Japanese with English summary)

Tochihara, H. 1965 Identification and serological comparisons of viruses causing mosaic diseases of Japanese radish. Bull. Nat. Inst. Agr. Sci., Series C, 18: 1-52 (in Japanese with English summary)

Tompkins, C. M. 1938 A mosaic disease of turnip. J. Agri. Res., 57: 589-602

Yoshii, H. 1963 On the strain distribution of turnip mosaic virus. Ann. Phytopath. Soc. Japan, 28: 221-227

Yoshii. H.. M. Sugiura and T. Iwata 1963 Studies on the Daikon Mosaic Virus (DMV), the Japanese strain of Turnip Mosaic Virus. Mem. Assoc. PI. Prot. Kyushu, 1: 1-26, 4 pls. (in Japanese with English summary) 